\title{
Epidemiological and clinical aspects of paediatric HIV infections in Setif (Algeria)
}

\author{
A Ouyahia*, M Rais, A Gasmi, S Mechakra, A Lacheheb \\ From International Symposium HIV and Emerging Infectious Diseases 2014 \\ Marseille, France. 21-23 May 2013
}

\section{Background}

Algeria has a low HIV prevalence and data on the risk factors and clinical presentation of HIV-infected children are lacking.

\section{Objective}

To describe the epidemiological, clinical characteristics and outcome of HIV-infected children in Setif.

\section{Methods}

A retrospective review was undertaken of the medical records of all patients admitted to the HIV unit of the teaching hospital of Setif which serves a population from a wide geographic catchment area, between January 2002 and November 2013.

\section{Results}

Of 286HIV-infected patients, 12 were children (4.1\%), $8(66.7 \%)$ of whom were male. Ages at diagnosis ranged from 6 months to 12 years (median 5).

Of the $10(83.3 \%)$ children who acquired the infection by vertical transmission, median age at diagnosis was 3 years. Only one woman was offered PMTCT interventions with HAART started lately at 38 weeks of pregnancy, oral AZT and replacement feeding to neonate.

All neonates were delivered by spontaneous vaginal delivery, 9 of them were breastfed throughout infancy.

Children commonly presented with prolonged fever (25\%), recurrent cough $(\mathrm{n}=33.3 \%)$, failure to thrive $(n=41.66 \%)$ and recurrent diarrhoea $(n=8.3 \%)$. One case had tuberculosis associated to herpes zoster, 2 cases of moluscum contagiosum, one case of anal condyloma and one case of visceral leishmaniosis. All cases received highly active antiretroviral. Of those $91.6 \%$ were compliant with

Ferhat Abbes University, faculty of medicine, Setif, Algeria treatment and had a sustained virologic response below the detectable levels. One child died at age of 6 months.

\section{Conclusion}

The majority of HIV-infected children presenting to our hospital acquired HIV through vertical transmission. A strong prima facie case for the introduction of mandatory HIV testing of pregnant women must be made because the price paid by HIV-infected newborns for their mothers' failure to undergo testing and treatment is very high.

Published: 23 May 2014

doi:10.1186/1471-2334-14-S2-P14

Cite this article as: Ouyahia et al:: Epidemiological and clinical aspects of paediatric HIV infections in Setif (Algeria). BMC Infectious Diseases 2014 14(Suppl 2):P14.
Submit your next manuscript to BioMed Central and take full advantage of:

- Convenient online submission

- Thorough peer review

- No space constraints or color figure charges

- Immediate publication on acceptance

- Inclusion in PubMed, CAS, Scopus and Google Scholar

- Research which is freely available for redistribution 